\title{
CAMUS LEITOR DE HEIDEGGER
}

(os limites de uma) proximidade conceitual entre angústia e absurdo

\author{
CAMUS, READER OF HEIDEGGER
}

(the limits of a) conceptual proximity between anxiety and absurd

\section{RESUMO}

O texto desenvolvido pretende evidenciar e examinar a influência de Martin Heidegger (1889-1976) sobre o pensamento filosófico de Albert Camus (1913-1960) e com isso sugerir uma proximidade, notadamente entre a concepção heideggeriana de angústia e a perspectiva camusiana acerca do absurdo, destacando ao cabo suas pertinentes diferenças. Para tanto, examinam-se ambos os conceitos, respectivamente no tratado Ser e tempo (publicado em 1927) e no ensaio filosófico O mito de Sísifo (publicado em 1942). Nesse sentido, os pontos de maior aproximação, de modo geral, recaem nos temas: condição humana, estranheza ou "estrangeiridade" e, sobretudo, existência autêntica. Oportuniza-se, com essa comparação, uma via que enriquece ainda mais o âmbito filosófico que há no pensamento camusiano.

Palavras-chave: Heidegger e Camus. Angústia. Absurdo. Condição Humana. Ser e Tempo.

\begin{abstract}
The developed article proposes to investigate Martin Heidegger's (1889-1976) influence on Albert Camus' (1913-1960) philosophical thinking, and, thus, suggest a closeness between Heidegger's conception of anxiety and Camus' thinking about the absurd. Therefore, we will investigate the respective conceptions in Being and Time (published in 1927) and in The Myth of Sisyphus (published in 1942). The elements of greater approximation are present in the following themes: human condition, strangeness, and, primarily, authentic existence. With this comparison, we emphasize and further highlight the philosophical scope of Camusian thought.
\end{abstract}

Keyword: Heidegger and Camus. Anxiety. Absurd. Human Condition. Being and Time.

\section{INTRODUÇÃO}

\footnotetext{
${ }^{1}$ Graduando em Filosofia pela Universidade Estadual de Santa Cruz (UESC).

CV Lattes: http://lattes.cnpq.br/7049256815418792.

ORCID: https://orcid.org/0000-0002-5040-878X.
} 
Nossa pretensão reside em sugerir e examinar certa proximidade, do ponto de vista filosófico, entre Martin Heidegger e o pensamento de Albert Camus. Segundo o Novo Dicionário da Língua Portuguesa, "proximidade" significa: "[do lat. proximitate] S. $f$. 1. Estado ou condição do que é ou se acha próximo; contiguidade. 2. Pequena distância de lugar ou de tempo; vizinhança, adjacência" (FERREIRA, 1986, p. 1410). Assim, procuraremos indicar uma proximidade conceitual especificamente entre a concepção heideggeriana de angústia e o pensamento camusiano do absurdo, utilizando sobretudo o tratado Ser e tempo e o ensaio de $O$ mito de Sísifo. Mas, afinal, qual seria a relevância em propor e, quiçá, explicitar uma vizinha conceitual entre os pensadores aqui em questão? Qual seria a importância de se constatar alguma aproximação entre dois autores aparentemente tão díspares?

Quando se pensa no quadro teórico de influências de Albert Camus, de algum modo há uma menor visitação quanto ao pensamento filosófico de Martin Heidegger. Em contrapartida, evidenciar o alcance heideggeriano no contexto teórico a partir do qual escreve Camus, equivale ir além das vertentes hegemônicas - do que se comentou e se pensou sobre o franco-argelino - que muitas vezes o limitam como mero ilustrador literário de teses filosóficas, como é o caso, por exemplo, de seu contemporâneo Jean-Paul Sartre (2005, p. $118)^{2}$. Conforme corrobora Guimarães (1971, p. 16): “Camus está em poucos manuais de história da filosofia e em qualquer manual de literatura". Perceber, no limite de um exagero, uma aproximação entre as economias internas do conceito heideggeriano de angústia e do absurdo camusiano será proveitoso na medida em que nos permite extrapolar as possibilidades de leitura de até então e oportunizar, com isso, uma via (não muito frequentada) que enriquece ainda mais o âmbito filosófico próprio a Camus.

Neste sentido, a tentativa de verificar um parentesco filosófico entre ambos os autores também pode sugerir, de alguma forma, uma tomada de posição quanto a determinada crítica dirigida a Camus, a saber, a de que sua concepção de absurdo comporta uma imprecisão conceitual, visto que o autor se refere ao termo absurdo ora como uma condição de fato na qual o homem está lançado, ora como um despertar da consciência. Por isso, alguns dos considerados mais importantes intérpretes da filosofia de Camus, tais como Emmanuel Mounier (1972), Pierre-Henri Simon (s/d) e o próprio Sartre (2005) questionam o francoargelino quanto a seu conceito de absurdo, indagando se este teria o sentido de uma condição em que inevitavelmente o homem está inserido ou se diz respeito apenas a uma questão de

\footnotetext{
${ }^{2}$ A crítica de Sartre, particularmente ao Estrangeiro e $O$ Mito de Sísifo marcou, até hoje, as principais vertente de tudo quanto se disse e se pensou sobre Albert Camus (BRISVILLE, 1962, p. 44).
} 
constatação do nível da consciência: "sob a pena de Camus essa palavra [absurdo] assume duas significações muito diferentes: o absurdo é ao mesmo tempo um estado de fato e a consciência lúcida que certas pessoas adquirem desse estado" (SARTRE, 2005, p. 117). Assim, a ambiguidade conceitual que supostamente pertence à concepção camusiana de absurdo cede lugar a uma melhor compreensão do termo, por assim dizer, se o analisarmos à luz do conceito heideggeriano de angústia, como sugerimos. Para tanto, é preciso inicialmente observar em que medida o filósofo da ontologia fundamental, Martin Heidegger, pertence ao quadro de inspiração teórica de Camus.

\section{CAMUS LEITOR DE HEIDEGGER?}

Com efeito, não se pretende, neste item, descrever de modo minucioso a formação intelectual de Camus, mas apenas abordar os nomes de maior expressão com os quais e a partir dos quais o autor se desenvolveu teoricamente. Nesse sentido, é possível seguramente constatar - com base na literatura especializada - os autores lidos por Camus (e em que medida este se aproximou ou se distanciou deles) e, sobretudo, os que exercerem maior influência sobre sua obra. Herdeiro de uma tradição que buscou integrar expressão literária e pensamento filosófico, de saída pode-se considerar determinado quadro teórico para Camus: devem-se considerar as figuras dos "moralistas franceses" (GERMANO, 2007, p. 14) - dos quais, diga-se de passagem, Camus teve decisiva influência em sua "mediterraneidade" (BRISVILLE, 1962, p. 70-71) -, tais como Chateaubriand, La Rochefoucauld, Vauvernagues, Chamfort e Vigny; dos romancistas-pensadores do século XVIII (Voltaire, Rousseau, Laclos), do século XIX (Dostoiévsky³ ${ }^{3}$, especialmente com Ivan Karamázov, e Nietzsche ${ }^{4}$ ) e do século

\footnotetext{
${ }^{3}$ Camus lê Dostoievski considerando-o, sobremaneira, um autor que realiza escavações em um mundo que matou Deus e relegou-o ao subsolo da História. Em A peste, escreve: “- Não, padre - disse ele [Rieux] - tenho outra ideia do amor. E vou recusar até à morte amar esta criação em que as crianças são torturadas" (CAMUS, 2001, p. 152). Essa é uma alusão explícita ao romance Irmãos Karamázov. No romance, Ivan Karamázov narra uma série de acontecimentos abjetos e doentios, especialmente contra crianças, e depois diz a Aliocha: "Compreendes esse absurdo, tem ele um fim, meu amigo e meu irmão, tu, o noviço piedoso?" (DOSTOIEVSKI, 1971, p. 181). Assim, para Ivan, se for necessário que uma criança seja maltratada, surrada ou castigada, ele rejeita veementemente Deus e toda sua criação, por mais que no fim haja redenção: "Imagina que, em definitivo, esse mundo de Deus, eu não o aceito e, embora saiba que ele existe, não o admito. Não é Deus que repilo, nota bem, mas a criação; eis o que me recuso a admitir" (DOSTOIEVSKI, 1971, p. 177). Depois diz: "E, se o sofrimento das crianças serve para perfazer a soma das dores necessárias à aquisição da verdade, afirmo desde agora que esta verdade não vale tal preço" (DOSTOIEVSKI, 1971, p. 183-4, grifo nosso). Tamanha era a singular admiração de Camus pela personagem Ivan Karámazov, que na sua juventude chegou mesmo a representá-la no teatro (BRISVILLE, 1962, p. 35). Ao cabo, vale também destacar a adaptação realizada po Camus de Os possessos. Quanto à relação entre os dois autores, cf. FONSECA, Ludmilla C. O homem
} 
XX (Malraux, Koestler e o próprio Sartre ${ }^{5}$ ); e mesmo de seus contemporâneos franceses (Aron, Merleau-Ponty, Queneau, Olivier, Paulhan, Simone de Beuvoir e Aragon), com os quais Camus certamente estabeleceu debates.

E não apenas isso; entre as cuidadosas leituras de Camus, sublinham-se também os nomes de Montherlant, Valéry, Gide, Faulkner, Molière, mas também de Søren, Kierkegaard ${ }^{6}$, Pascal, Epiteto e dos estoicos (BRISVILLE, 1962, p. 36/99). Destaca-se o de Blaise Pascal: ao apontar os limites da razão humana em plena hegemonia filosófica do projeto racionalista de modernidade, no século XVII, Pascal e sua visão cristã-trágica do homem recebem expressiva recepção por Camus. ${ }^{7}$ Indo além, a própria tese de Albert Camus (sobre "helenismo e cristianismo") nos revela atenta pesquisa na qual compara o pensamento de Plotino $^{8}$ com o de Agostinho. Finalmente, não poderiam faltar os nomes reconhecidos pelo próprio franco-argelino (CAMUS, 2004), como os de Shakespeare, Balzac, Kafka, Herman Melville e Hemingway.

Mas, afinal, qual é o lugar de Heidegger, particularmente, na ascendência filosófica de Camus? Essa indagação se sobressai principalmente quando se avaliam as particularidades em torno de cada autor: por um lado, um fenomenólogo europeu envolvido em polêmica com o nazismo e cujo leitmotiv encerrou-se abstratamente em torno do pensamento sobre o sentido do ser em geral; por outro lado, um pensador que cresceu debaixo do implacável sol da costa do norte da África, cuja obra dispensa a clarividente racionalização - e, antes, convida o leitor a sentir a grandeza do homem, do mar, da terra. Diga-se de passagem, há quem afirma que

extraordinário de Fiódor Dostoiévski e o homem revoltado de Albert Camus. 124 f. Dissertação de Mestrado Universidade de Brasília, 2010.

${ }^{4}$ No que diz respeito à leitura que Camus faz de Nietzsche, sugere-se o excelente trabalho: ALVES, Marcelo. Camus: entre o sim e o não a Nietzsche. 127 f. Dissertação de Mestrado - Universidade Federal de Santa Catarina, Florianópolis, 1998.

${ }^{5}$ No que diz respeito à relação filosófica entre os dois autores, cf. FAVERO, Roberto C. Humanismo: uma releitura existencial de Albert Camus e Jean-Paul Sartre. 109 f. Dissertação de Mestrado - Universidade do Vale do Rio dos Sinos, São Leopoldo, 2006.

${ }^{6}$ Quanto à veemente influência de Kierkegaard sobre Camus, cf. OLIVEIRA, Márcio Alves. Um significativo lado obscuro da modernidade modernizadora - à luz de Kierkegaard e Camus. 225 f. Dissertação de Mestrado. Universidade de São Paulo, São Paulo, 2004.

7 Dentre vários elementos em comum, destaca-se aquele que talvez seja central na relação Pascal-Camus: o posicionamento enfático contra a pretensão racionalista de captar e explicar a suposta essência do mundo. Para Pascal, o homem é incapaz de qualquer conhecimento do âmago; o homem configura-se enquanto ser miserável e extraviado, sempre sujeito à mudança e ao devir, com uma duração de vida efêmera. E mais: o homem é "barro miserável" (PASCAL, 1965, p. 44), sendo, naturalmente (depois da queda adâmica), infeliz e fraco, mentiroso e hipócrita, tedioso e fastioso, vão, vazio e medíocre (PASCAL, 1965, p. 106), alcançando, assim, o posto de mais fraco da natureza, tal qual um caniço. Para melhor aprofundamento dessa forte relação filosófica, cf. GERMANO, Emanuel R. O pensamento dos limites: contingência e engajamento em Albert Camus. 498 f. Tese de Doutorado - Universidade de São Paulo, São Paulo, 2007.

${ }^{8}$ Camus tem erudito e vasto conhecimento sobre os gregos, como se verifica n' O homem revoltado (CAMUS, 2008, p. 45). Quanto à influência do pensamento grego sobre Camus, cf. SAPATERRO, Fernando R. Albert Camus: a felicidade e a relação homem-natureza em diálogo com Epicuro. $136 \mathrm{f}$. Dissertação de Mestrado Pontifícia Universidade Católica de São Paulo, São Paulo, 2005. 
Camus sequer compreendeu corretamente Heidegger - para ficar com dois expressivos exemplos: Brisville (1962, p. 52) e Sartre (2005, p. 119). Todavia, observa-se a importância desse alemão no pensamento de Camus, por exemplo, quando ele diz (CAMUS, 2004) que Heidegger (junto a Nietzche) foi um dos poucos a considerarem filosoficamente o absurdo e nele se manterem sem esperança e sem salto. De Dostoiévski a Kierkegaard, de Jaspers a Chestov, de Scheler a Husserl: todos esses filósofos têm em comum o tema do absurdo como ponto de partida existencial, mas todos mostram decepcionante pressa para dali fugir, seja pelo salto religioso (Jaspers, Kierkegaard, Dostoiévski) ou pelo salto racional (Chestov, Scheler, Husserl). O irracional é por eles justificado e por isso mesmo deixa de ser irracional. Tais autores "partiram do universo indizível em que reinam a contradição, a antinomia, a angústia ou a impotência" (CAMUS, 2004, p. 37), isto é, perceberam a falta de sentido entre o homem e o mundo, porém logo trataram de forjar uma saída filosófica para essa questão. Assim, a consideração de Camus pela figura de Heidegger é central, visto que seu pensamento, longe de propor uma evasão, sustenta-se, pelo contrário, no problema fundamental da filosofia, a saber, o absurdo. "Só existe um problema filosófico realmente sério: o suicídio. Julgar se a vida vale ou não vale a pena ser vivida é responder à pergunta fundamental da filosofia." (CAMUS, 2004, p. 17) Camus não só compreendeu Heidegger; mais do que isso, ele o percebeu como um dos filósofos fundamentais, já que sua postura filosófica perante o absurdo negligencia uma saída e, pelo contrário, mantém-se nesse confronto desesperado entre a interrogação humana e o silêncio irracional do mundo, permanecendo sem esperanças, sem fundamento, sem clarividência racional, sem Deus (CAMUS, 2004).

Ademais, tal como frisam muitos dos intérpretes heideggerianos, o filósofo alemão exerceu grande influência de modo geral sobre o século XX, especialmente por conta da publicação de sua obra-mestra:

Heidegger exerceu uma influência imensa, embora difusa, sobre a filosofia do século XX. Na Alemanha, depois de se impor, no começo da década de 1920, como o rei oculto do pensamento, ele ganhou celebridade quase instantânea com a publicação de Ser e tempo. (LOPARIC, 2004, p. 62)

E não só na Alemanha: "Toda a elite intelectual jovem da Alemanha, da França, do Japão e de vários outros países procurou estudar com Heidegger” (LOPARIC, 2004, p. 9). É verdade que a recepção da filosofia heideggeriana é problemática, de certo modo, em contexto francês, em vista da repercussão de seu envolvimento 
com o nazismo gerada pelo livro Heidegger e o nazismo: "Desde a obra de jornalismo barato de Vítor Farias intitulada Heidegger e o nazismo, uma obra lançada na Alemanha na década de 1980 com um prefácio de Jürgen Habermas, mas que teve enorme repercussão na França [...]" (CASANOVA, 2009, p. 150). A despeito dessa repercussão, não deixa de ser notório que a filosofia heideggeriana se fez presente na atmosfera intelectual francesa, como ressalta um dos principais biógrafos de Martin Heidegger:

A influência de Heidegger na França começara em inícios dos anos trinta [Mito de Sísifo foi publicado em 1942] no contexto de uma corrente intelectual a que Jean Wahl e Gabriel Marcel tinham dado no fim dos anos vinte o nome "existencialismo". (SAFRANSKI, 2000, p. 401)

Corrobora-se ainda mais a notoriedade da presença do pensamento heideggeriano na atmosfera francesa, principalmente quando se destacam dois fatores: (i) a filosofia alemã contemporânea de modo geral - mas sobretudo a corrente metodológica em que Heidegger se inseria - já se fazia presente no contexto intelectual francês:

Na formação desse ambiente do existencialismo francês [...], onde mística do ser, decisionismo da graça, absurdismo e nihilismo se encontram num terreno comum anticartesianismo, atua, como mais um poder intelectual, a fenomenologia. Desde os anos vinte a França descobre Husserl e Scheler. (SAFRANSKI, 2000, p. 402)

E (ii), a relevância de Ser e tempo, obra considerada, segundo destaca Ernildo Stein, como a "que levantou o maior número de questões filosóficas centrais no século XX, em comparação com qualquer outra obra de nosso tempo" (STEIN, 2005, p. 7). Ademais, observa o intérprete francês Jean-Paul Resweber, Ser e tempo é a obra "mais marcante da filosofia do século XX” (RESWEBER, 1979, p. 23). Tal influência impactante se deu, inclusive, sobre autores com os quais ou contra os quais Camus dialogava, mas que de todo modo mantinhamse em seu contexto:

A presença de Heidegger na França é um assunto à parte [...]. Além de trabalhos de Levinas, Sartre, Merleau-Ponty, Foucault e Derrida, os de Pierre Aubenque, Michel Haar, Jean-Luc Marion e Jean Greisch revelam profundas marcas do mestre alemão. (LOPARIC, 2004, p. 63)

Nesse sentido, aproximar Camus de Heidegger equivale a ir além das interpretações já há muito esmiuçadas, as quais veem no pensador da costa 
argelina no máximo uma literatura-filosófica (SARTRE, 2005; MOUNIER, 1972). Compreender um autor exige disposição para refazer sua trajetória, a fim de evidenciar aquilo que o próprio autor já compreendeu e pelo que escolheu se influenciar. Identificar o alcance heideggeriano no contexto intelectual de Camus corresponde a trabalhar por dentro de seu pensamento de modo a melhor entendê-lo: colocamos nisso a proposta segundo a qual o conceito de angústia - e todo o seu corolário, que necessariamente traz à tona em Ser e tempo - é situado por Camus no mesmo plano do absurdo.

\section{HEIDEGGER E A ANGÚSTIA}

Para Heidegger, angústia (Angst) está como condição (ontológica) do Dasein inicialmente, porque ela permite acessar a totalidade originária mais básica e elementar da estrutura do Dasein, a cura (Sorge). ${ }^{9}$ Nesse sentido, Heidegger procura por um fio condutor que o permita acessar justamente esse fundamento mais originário (PEREIRA, 2008, p. 65). Eis, então, que o filósofo alemão encontra sua resposta: "O fenômeno da angústia foi colocado à base da análise como uma disposição suficiente que atende tais exigências metodológicas" (HEIDEGGER, 1988, p. 245). Quer dizer, uma vez conquistado essa totalidade estrutural (cura), Heidegger encaminha uma exigência método-fenomenológica de como abrir originariamente essa totalidade - de modo que sua estrutura se mantenha unificada nesse acesso -, e encontra justamente na disposição fundamental da angústia tal chave de acesso. Daí o porquê de a angústia, em primeiro momento, estar como condição ontológica do Dasein: ela oferece o solo fundamental para a apreensão da totalidade originária desse ente. Além disso, Heidegger busca a angústia na própria estrutura ontológica do Dasein, e assim nos permite des-ocultar e alcançar justamente "o ser da totalidade do todo estrutural" (HEIDEGGER, 1988, p. 247). Assim, Heidegger indica a disposição fundamental da angústia como fenômeno mais originário, que funciona metodologicamente como disposição de abertura.

Ademais, angústia está como condição (ontológica) do Dasein porque - diferente do fenômeno do "temor" - a própria constituição fundamental do Dasein já traz à tona a possibilidade da angústia. Com efeito, deve-se ressaltar o fato de que há, por assim dizer,

\footnotetext{
${ }^{9}$ Cura é o fenômeno mais originário que revela a totalidade estrutural do Dasein, e que só por isso est relacionado com a existência autêntica.
} 
certa consanguinidade entre os fenômenos "angústia" e "temor", de modo que às vezes "se chama de angústia o que é temor e se fala de temor quando o fenômeno possui o caráter de angústia” (HEIDEGGER, 1988, p. 249). Atento a essa sutileza, Heidegger logo se propõe diferenciar ontologicamente de forma clara um elemento do outro: no limite, o que distingue fenomenalmente o "temor" da "angústia" é o objeto pelo qual o primeiro teme. O que se teme é um ente que está dentro do mundo, e ele só é temível justamente por abrir um mundo de ameaças potenciais. Teme-se, por exemplo, o resultado de uma consulta médica de cisto no útero, na medida em que ela traz a possibilidade de ameaça ou dano. Portanto, a potencial ameaça está (i) precisamente disposta em um contexto conjuntural: resultado clínico positivo de cisto no útero, cirurgia, saúde debilitada, licença médica etc.; e (ii) o determinado dano refere-se a determinado âmbito/região daquilo de que vai ao encontro: ameaça específica da saúde da mulher. Por último, essa possibilidade de ameaça que jaz na espera de uma consulta médica está relacionada com uma ameaça tácita: o resultado da consulta não está numa proximidade, rigorosamente falando, mas está próximo de uma maneira sutilmente subjacente, de modo que a qualquer momento pode (ou não) se irradiar e efetivar o caráter de ameaça.

Preocupado com certa semelhança entre "temor" e "angústia", Heidegger então procura rematar a distinção entre ambos os fenômenos. Primeiramente, a angústia não se angustia, de modo algum, com determinado ente que está dentro do mundo; na verdade, "o com quê da angústia é inteiramente indeterminado" (HEIDEGGER, 1988, p. 250). A possibilidade da angústia, portanto, não está relacionada com a possibilidade de ameaça ou dano de determinado ente que nos vem ao encontro dentro do mundo. A angústia não sabe o que é aquilo com que se angustia, visto que não há algo propriamente dito com o qual se angustia. Se angústia não traz a ameaça de um ente definido, ela carece então de conjuntura ou seja, a angústia não se angustia com algo específico e por isso mesmo não estabelece conjuntura, porque somente entes intramundanos possuem conjuntura (INWOOD, 2002, p. 8). Portanto, por um lado, no caso do "temor" (ainda com o exemplo mencionado) aquilo que se teme (resultado da consulta médica) é um ente intramundano que, visando determinada região daquilo de que vai ao encontro (saúde debilitada do ente humano), torna-se, de modo tácito, possivelmente mais próximo e por isso possivelmente mais ameaçador. Por outro lado, porém, assim não procede a angústia - e por que não? Justamente porque com ela o mundo torna-se insignificante, perde sentido (pouco importa esse ou aquele ente). Ou seja, ela se angustia com o mundo como tal (e não com determinada região), e isso 
significa que a própria constituição fundamental do Dasein já traz à tona a possibilidade de angústia, visto que "mundo" é em si mesmo um constitutivo do Dasein. A expressão ser-nomundo, já em sua composição, dirige-se a um fenômeno de unidade e não de fragmentação de mais de um elemento (o "ser" "no" "mundo").

Heidegger completa seu raciocínio: "Aquilo com que a angústia se angustia é o serno-mundo como tal" (HEIDEGGER, 1988, p. 249, grifos do autor). Nota-se, então, que não se trata de algo que a qualquer momento pode ou não se efetivar e assim propiciar a angústia, mas o próprio mundo como tal já traz à tona a possibilidade da angústia. Em vista disso, Stegmüller corrobora: “Ao contrário do medo [temor], que se dirige sempre para alguma coisa determinada [...], falta na angústia um objeto determinado, algo com que se fique angustiado. Ela é sem fundamento, mas, ao mesmo tempo, de uma totalidade absoluta" (STEGMÜLLER, 1977, p. 130). A totalidade a que se refere Stegmüller está ligada à angústia na medida em que tal disposição não diz respeito a uma mera faceta do homem ou da mulher (a saúde, por exemplo), ou a determinada totalidade conjuntural, mas sim ao "todo o ser do homem com todas as suas relações com o mundo" (STEGMÜLLER, 1977, p. 130, grifos do autor). A angústia, enfim, está ligada ao próprio ser-no-mundo como tal: "a angústia se angustia com o próprio ser-no-mundo" (HEIDEGGER, 1988, p. 251, grifos do autor).

Com efeito, a disposição da angústia implica, de acordo com Heidegger, um fenômeno originário do Dasein, qual seja, o de sentir-se estranho. Antes de tudo, isso se deve porque aquilo que a angústia propicia é o nada, isto é, a total falta de sentido do mundo. Visto que a angústia se angustia com o mundo como tal (e não com determinada região), isso equivale a concluir que aquilo com que ela se angustia é o nada (a nadificação de um mundo insignificante). "Fenomenalmente, a impertinência do nada e do em parte alguma intramundana significa que a angústia se angustia com o mundo como tal." (HEIDEGGER, 1988, p. 250, grifos do autor) A total insignificância que se anuncia no nada revela que um ente intramundano, em si mesmo, tem pouca relevância em termos de apresentar alguma ameaça para angústia. Por isso o angustiar-se abre, de modo originário, o mundo como mundo, pois o abre enquanto nadificação de sua insignificância - a angústia despe o mundo de sua totalidade de sentido (INWOOD, 2002, p. 8). Além disso, a angústia não se angustia com a proximidade tácita de um ente intramundano; o próprio mundo enquanto tal (isto é, o nada) já é assaz para o surgimento do fenômeno da angústia. O angustiar-se abre de modo originário, e por isso mesmo primário, o mundo como mundo (a nadificação de um mundo insignificante) e "mundo" diz sempre ser-no-mundo. 
A segunda razão pela qual a angústia implica o mencionado fenômeno originário do Dasein, o sentir-se estranho, é por revelar o próprio Dasein de forma nua e crua, isto é, revelálo também despido de qualquer sentido. Assim, se é correto considerar que a angústia despe o mundo de sua totalidade de envolvimento significativo (INWOOD, 2002, p. 8), pode-se dizer que ela também despe o próprio Dasein de seu envolvimento significativo, desnudando-o, então, em seu ser-próprio nu e cru, em seu próprio pode-ser. Uma vez que a angústia realiza a abertura originária e primária do mundo como mundo e do ser-no-mundo como ser-nomundo, já não é mais possível ao Dasein perder-se, por assim dizer, na decadência ao se deixar absorver pelas ocupações. "A angústia retira, pois, do Dasein a possibilidade de, na decadência, compreender a si mesmo a partir do 'mundo' e na interpretação pública" (HEIDEGGER, 1988, p. 251); ou seja, a disposição da angústia retira a possibilidade de o Dasein imergir-se na decadência, que, diga-se de passagem, é o modo específico de abertura do Dasein em sua cotidianidade, em que ele foge de si mesmo ao se deixar absorver pelas ocupações (ou, o que significa em última análise o mesmo: a angústia retira a possibilidade de o Dasein perder-se a si mesmo ao estar no modo da impropriedade). Daí o porquê de Heidegger considerar o fenômeno da angústia como disposição privilegiada e fundamental a qual empreende abertura: a angústia remete ao Dasein e o singulariza para seu próprio poderser-no-mundo, para a liberdade de assumir e escolher a si mesmo; a angústia remete e singulariza o Dasein para a propriedade de seu próprio ser. A angústia é a chave de acesso à existência autêntica justamente porque ela despe o Dasein de seu envolvimento significativo, desnudando-o, então, em seu ser-próprio nu e cru, em seu próprio poder-ser.

Portanto, visto que a angústia des-encobre o Dasein nu e cru e seu mundo insignificante e indiferente, podemos concluir, com Heidegger, que a angústia faz com que achemos tudo "estranho" (sem lar). Angustiado, o Dasein sente-se fora de casa como ser-nomundo - "estranho" indica "não se sentir em casa". Seguindo o fio condutor, Stegmüller comenta:

Aqui já entra em jogo toda a disposição fundamental da Filosofia da Existência: o mundo em que vivemos é absolutamente incompreensível, absurdo. Como é possível uma vida autêntica, que não negue artificialmente a estranheza do mundo, mas que seja capaz de olhá-lo de frente? $\mathrm{Na}$ disposição mostra-se para o homem, sobretudo, sua falta de segurança íntima. Nisso a angústia [sic] ocupa um lugar central. (STEGMÜLLER, 1977, p. 129-130) 
Não obstante, eis a indeterminação característica em que se encontra o Dasein uma vez na angústia: o de estranheza (Unheimlichkeit). Sentir-se imerso na impessoalidade quer dizer sentir-se enraizado, acolhido, sentir-se em casa; em contrapartida, sentir-se angustiado quer dizer desenraizamento, desterro, desabrigo. Assim, a angústia retira o Dasein de seu empenho decadente no mundo, rompendo, então, a familiaridade tranquila de seu cotidiano. Assinala-se, por um lado, que o modo cotidiano em que o Dasein compreende a estranheza reside em um desvio para a decadência, ou seja, em seu modo cotidiano o Dasein procura fugir dessa estranheza "que, na maior parte das vezes, permanece encoberta pela angústia latente, uma vez que a publicidade do impessoal reprime toda e qualquer não familiaridade" (HEIDEGGER, 1988, p. 257). Por outro lado, entretanto, a angústia traz à tona justamente a “estranheza inerente ao Dasein enquanto ser-no-mundo lançado para si mesmo em seu ser" (HEIDEGGER, 1988, p. 253).

Indo além, pode-se observar que a angústia libera o Dasein de sua decadência do mundo cotidiano no qual ele procura fugir da estranheza que assola sua existência. A angústia retira o Dasein de seu empenho decadente no mundo, em que ele permanece encoberto para si mesmo uma vez na interpretação pública do impessoal. Com efeito, na convivência cotidiana constitutiva do ser-com reside aquilo que Heidegger (1988, p. 179) tratou por impessoal. Neste, o Dasein não é ele próprio, e sim os outros que lhe tomam o ser. Nesse caso, as possibilidades cotidianas de ser do Dasein são, por assim dizer, ofuscadas pelo lugar comum dos outros. Mas o que Heidegger tem em vista, afinal, ao utilizar o termo "outros"? Trata-se de qualquer outro: nós, a gente, eles, todos, ninguém. Não há distinção ou especificidade. Eis, portanto, a ditadura do impessoal da qual o Dasein não se dá conta, e nisso incide tal domínio ditatorial: o Dasein é pulverizado no modo de ser dos outros na medida em que o "a gente", isto é, o impessoal, é quem prescreve o modo de ser da cotidianidade. "Este conviver dissolve inteiramente o próprio Dasein no modo de ser dos 'outros' e isso de tal maneira que os outros desaparecem ainda mais em sua possibilidade de diferença e expressão.” (HEIDEGGER, 1988, p. 179) A especificidade do modo de ser do Dasein apaga-se na impessoalidade - por exemplo, em seu entretenimento, em sua diversão, na utilização diária dos meios de transporte, na leitura e julgamento de literatura e de arte, no uso comum dos meios de comunicação, o Dasein passa a considerar "revoltante" o que impessoalmente se considera revoltante; numa palavra, cada um é como o outro no cotidiano em geral, e nisso reside a ditadura do "bando", do "a gente" ou do "nós". Desse modo, a ditadura da impessoalidade retira a responsabilidade do Dasein de assumir seu próprio ser na 
cotidianidade. Devido ao fato de se colocar como guia, prescrevendo e orientando toda deliberação e decisão do Dasein, o "nós" retira dele a responsabilidade de ter de assumir seu próprio ser. "O impessoal pode, por assim dizer, permitir-se que se apoie impessoalmente nele. Pode assumir tudo com a maior facilidade e responder por tudo, já que não há ninguém que precise responsabilizar-se por alguma coisa.” (HEIDEGGER, 1988, p. 180) O impessoal vem de modo superficial ao encontro do Dasein, dispensando-o de se decidir com seu ser eis, então, que ele solidifica e espraia seu “domínio caturro” (HEIDEGGER, 1988, p. 180).

Uma vez atingido pela angústia, o Dasein se compreende de forma autêntica, e não inautêntica, isto é, compreende-se a partir de si próprio e não mais a partir dos outros (que visam a lhe tomar o ser). Atingido pela angústia, o Dasein não é mais pulverizado no modo de ser dos outros, em que o "a gente", isto é, o impessoal, espraia-se. Assim, a angústia libera o Dasein do domínio da impessoalidade, no qual se retira a responsabilidade do Dasein de assumir seu próprio ser:

O impessoal pode, por assim dizer, permitir-se que se apoie impessoalmente nele. Pode assumir tudo com a maior facilidade e responder por tudo, já que não há ninguém que precise responsabilizar-se por alguma coisa. (HEIDEGGER, 1988, p. 180)

Ao romper a familiaridade tranquila do Dasein cotidiano - desnudando-o e revelando um mundo indiferente e portanto estranho -, a angústia enquanto disposição fundamental singulariza o Dasein liberando-o para a autenticidade de seu próprio ser. A angústia permite-o compreender sua existência de fato, ou seja, a angústia libera a compreensão do Dasein para a facticidade, para seu existir de fato como ser-no-mundo - "a angústia se angustia com o serno-mundo lançado" (HEIDEGGER, 1988, p. 255) -, visto que o estar-lançado diz respeito ao limite fático no interior do qual o Dasein coloca em jogo seu próprio ser. Nisso reside todo o empenho enfático e veemente que Heidegger confere por excelência ao fenômeno da angústia: a angústia é responsável pelo trânsito ontológico da situação na qual o Dasein imerge no impessoal (ou seja, nessa condição em que ele procura fugir de si mesmo, não se colocando, portanto, diante de si mesmo) para outra condição, em que, uma vez angustiado, o Dasein coloca-se diante de si mesmo a partir de seu próprio ser.

\section{CAMUS E O ABSURDO}


Para Camus, o absurdo é condição do homem. ${ }^{10}$ A fim de explicitá-lo, devem-se abordar determinadas críticas feitas a Camus. Com efeito, dentre as principais objeções à perspectiva camusiana de absurdo (MACHADO, 2010, p. 44), destacam-se as realizadas à própria natureza do conceito: seria o absurdo uma condição de fato ou propriamente uma consciência? Nesse sentido, alguns comentadores - por exemplo, Emmanuel Mounier (1972, p. 67-68), Pierre-Henri Simon (s/d, p. 74) e Jean-Paul Sartre (2005, p. 119) - questionam Camus a respeito de tal conceito, indagando se este diz respeito a uma condição em que inevitavelmente o homem está inserido ou apenas a uma questão de constatação do nível da consciência. Tais críticos se apoiam na própria ambiguidade sugerida por Albert Camus, quando ele, em seu ensaio $O$ mito de Sísifo, ora fala em "sentimento do absurdo" (CAMUS, 2004, p. 43), ora em "noção do absurdo" (CAMUS, 2004, p. 43) - vê-se, então, que em alguma medida as objeções desses três críticos têm suas razões, já que Camus de sugere certa ambiguidade conceitual de absurdo. Todavia, a fim de contemplarmos tais julgamentos, devemos recorrer ao próprio Camus quando ele reitera excessivas vezes, em $O$ mito de Sísifo, que o absurdo não depende da vontade do homem, visto que se trata justamente de uma condição essencial: "O absurdo e o acréscimo de vida que comporta não dependem então da vontade do homem" (CAMUS, 2004, p. 74, grifos do autor). Ou seja, uma vez que o absurdo independe de o homem "querê-lo" ou não, sugere-se que o absurdo é estado fundamental da condição humana, isto é, ponto de partida existencial, independentemente da vontade do homem. E mais: n'O homem revoltado, Camus ressalta que "a revolta metafísica é o movimento pelo qual um homem se insurge contra a sua condição" (CAMUS, 2008, p. 39, grifo nosso). Afinal, a que "condição" se refere Camus? Precisamente à absurda.

A própria questão da solidariedade, extremamente cara à obra de Camus (especialmente n'A peste), sugere que o absurdo consiste fundamentalmente em uma condição: os homens de maneira geral estão jogados à gratuidade do mundo; nesse sentido, todos são estrangeiros e por isso mesmo irmãos. "A solidão, abandono e indigência do homem trazem a comiseração por uma condição a que todos estamos jogados. Solidários, porque solitários." (GUIMARÃES, 1971, p. 34) ${ }^{11}$ Assim, o absurdo é “a inadequação ontológica entre homem e mundo" (PIMENTA, 2010, p. 112, grifo nosso), o que tendencialmente nos lembra de Heidegger, quando afirma que angústia está como condição

\footnotetext{
${ }^{10}$ Por isso mesmo, nota-se de antemão que Camus mostra-se antiexistencialista, visto que o absurdo é a condição de homem, quer dizer, o homem está, por "essência", como homem-estrangeiro.

11 "Pelo que temos em comum, atinjo uma compreensão do outro que é solidariedade. A solidariedade daquilo que temos a afirmar. A solidariedade de uma condição." (GUIMARÃES, 1971, p. 66)
} 
ontológica do Dasein, já que está ligada ao próprio ser-no-mundo como tal: "a angústia se angustia com o próprio ser-no-mundo" (HEIDEGGER, 1988, p. 251, grifos do autor).

Em um segundo momento, explicita-se que o absurdo está como condição do homem, sobretudo quando se considera que ele reside precisamente na coexistência entre homem e mundo, de sorte que o absurdo não jaz especificamente nem no homem nem no mundo, mas na própria separação entre homem e mundo. Por isso, o absurdo consiste no divórcio de duas partes: o homem em sua busca de sentido e o mundo com seu (decepcionante) silêncio. "Esse divórcio entre o homem e sua vida, o ator e seu cenário é propriamente o sentido do absurdo." (CAMUS, 2004, p. 20) Nisso reside o sentido do "divórcio": o apetite humano pela unidade racional que só encontra, porém, a irredutibilidade desse mundo a um princípio racional e razoável. Ou seja, o homem busca familiaridade e conciliação com o mundo, e o mundo, por sua vez, oferece tão somente um silêncio irracional. Assim, o que os une é justamente o que os separa: o absurdo. O único laço entre homem e mundo é o absurdo: "Absurdo é o confronto entre o irracional e o desejo desvairado de clareza cujo apelo ressoa no mais profundo do homem" (CAMUS, 2004, p. 35); “O absurdo nasce desse confronto entre o apelo humano e o silêncio irracional do mundo" (CAMUS, 2004, p. 41).

Em seu texto A queda, Camus diz, através da boca de Jean-Baptista Clamence, "E depois, vamos direto ao ponto, eu amo a vida, eis a minha verdadeira fraqueza. Amo-a tanto, que não tenho nenhuma imaginação para o que não for a vida" (CAMUS, s/d, p. 60). O raciocínio absurdo admite a vida como bem necessário, porque permite justamente o mencionado confronto. Com efeito, a árvore, o gato, estes não possuem a condição de estrangeiro diante do mundo - tais entes fazem parte de seu mundo. O gato não é separado de seu mundo, ele "é" esse mundo. Ao contrário dessa situação, o homem encontra-se, ele sim, em uma condição de exilado.

Daí o porquê de Camus rejeitar veementemente a esperança e o suicídio como soluções para o absurdo, pois, diferente de uma saída desta condição, ele zela justamente por sua conservação. Quer dizer, uma postura absurda sustenta a manutenção do confronto desesperado entre a interrogação humana e o silêncio irracional do mundo. Ter esperança ${ }^{12}$ pelo além-mundo ou forjar a morte através do suicídio são vias (na verdade, fugas) por excelência não absurdas. Camus nega a esperança e recusa o suicídio, já que o suicídio mata (nega) o homem e a esperança nega (mata) este mundo, o que equivale a afirmar que a

${ }^{12}$ Em O estrangeiro, Camus escreve: "Marie me gritou [visitando Mersault na cadeia] que era preciso ter esperança. - Sim - concordei. Ao mesmo tempo, olhava-a e sentia vontade de apertar-lhe o ombro por cima do vestido. Tinha desejo por esse tecido delicado e, fora isso, não sabia muito bem em que havia de ter esperança”, (CAMUS, 1995, p. 78-79). 
esperança ou o suicídio constituem uma evasão da condição de absurdo, visto que o absurdo depende da coexistência entre homem e mundo. Matar-se ou saltar filosoficamente são maneiras de suprimir o absurdo, não de solucioná-lo.

Com efeito, o absurdo implica, de acordo com Camus, a condição do homem de sentir-se estranho - "Para sempre serei estranho a mim mesmo" (CAMUS, 2004, p. 33). Em primeiro lugar, isso se deve ao fato de que aquilo que o absurdo traz à tona é justamente a total falta de sentido que jaz na relação homem-mundo; quer dizer, o ser humano deseja reconciliar-se com o mundo conferindo-lhe um sentido e exaltando a unidade. Os desejos de unidade e o de verdade absoluta do universo, presentes no apetite humano (instinto de verdade), lançam-se na empreitada (inevitavelmente fracassada) de tentar abarcar racionalmente o mundo e captá-lo em sua essência última, fixa e una (GUIMARÃES, 1971, p. 55). Por "busca" de sentido, devemos entender o instinto de verdade do ser humano de acabar com a fratura, com o fosso entre seu espírito e o mundo; o homem tenta se familiarizar (o exato oposto de estranheza) com o mundo ao colocar-se a tarefa de ordená-lo em uma unidade teleológica e, assim, sair da condição de estranheza. Albert Camus denomina tal tentativa de conferir unidade, clareza e familiaridade com o mundo de nostalgia da unidade: o mundo é enxergado pelo homem segundo seus filtros e é mensurado segundo suas medidas. Em sua sede de conferir sentido ao mundo, o homem compreende-o através da ciência: classifica fenômenos, enumera leis e regras, sistematiza teorias, realiza descrições perfeitas e lança hipóteses esclarecedoras. A ciência pode apresentar à humanidade um mundo que ela diz estar ordenado, examinado e à mercê do homem; pode mostrar um mundo cheio de regras e leis universais, de todos os objetos de investigações científicas. A despeito disso, a ciência nunca captará o mundo em sua totalidade de sentido - em seu suposto recôndito mais profundo -, pois, diante da condição absurda, o que há é a total falta de sentido que jaz na relação homemmundo (GUIMARÃES, 1971, p. 51).

Desse modo, relacionar-se com o mundo nu e cru, isto é, despido de sentido, significa em Camus relacionar-se com o mundo de forma "desumana", quer dizer, rejeitar o recurso inteligível de mensuração (de medidas humanas) e enxergá-lo apenas sensivelmente, tal como se apresenta. De alguma forma, isso nos remete ao pensamento de Heidegger, no sentido de que a angústia traz à tona a total falta de sentido do mundo. Em sua tese de doutorado, Newton Pereira (2008, p. 69) ressalta: "Dasein angustiado sente-se em vertigem em um mundo que lhe é hostil, melhor dizendo, que lhe é indiferente. Na linguagem de Camus, o mundo revela-se como 'absurdo"'. 
Angustiado, o Dasein sente-se fora de casa como ser-no-mundo. Na angústia, o Dasein está "estrangeiro" e o mundo, "absurdo". A angústia propicia justamente a "estranheza inerente ao Dasein enquanto ser-no-mundo lançado para si mesmo em seu ser" (HEIDEGGER, 1988, p. 253).

Toda dimensão que extrapole o terreno da visão da praia, do cheiro da areia e do som do mar nada mais é senão um artificial recurso que o homem constrói a fim de afastar seu divórcio do mundo e, ao contrário, pintá-lo como familiar a ele. Perceber que no fundo de toda beleza jaz algo de desumano corresponde a notar que o mundo escapa ao homem e volta a ser ele mesmo. "Aqueles cenários disfarçados pelo hábito voltam a ser o que são." (CAMUS, 2004, p. 29) Compreender o mundo despido das medidas do homem compreender o mundo enquanto mundo inumano - corresponde a reconhecer o absurdo: "o mundo suspira para mim, com um ritmo longo, e me traz a indiferença e a tranquilidade daquilo que não morre" (CAMUS, 2007, p. 59); "Atrás de mim, uma a uma, as cigarras inflam suas vozes e depois contam: um mistério no céu, de onde caem a indiferença e a beleza" (CAMUS, 2007, p. 88). O coração que há no homem, o mundo que ele toca, isso existe e essa é sua maior ciência - o resto é construção do selo humano. Do mundo, o homem só pode conhecer - leia-se "experimentar" - sua grandeza e potência. De acordo com Guimarães:

A natureza sentida de modo intenso traz a vivência do essencial. Sob a grandeza do mundo nós nos elevamos e tudo mais se torna reduzido. Todos os problemas que levávamos aparecem como medíocres e inumanos. Estamos em nossa verdadeira dimensão e todas as outras são artificiais. (GUIMARÃES, 1971, p. 27, grifo nosso)

Ou seja, ao implicar a condição de sentir-se estranho, o absurdo sugere ao homem e à mulher existir sem apelar, sugere não haver sentido algum que ultrapasse este mundo, sugereque o que existe é o que a condição sensível do ser humano pode alcançar - o resto é tentativa de conciliação com o mundo, é busca desesperada por thelos.

Seguindo o fio condutor, pode-se afirmar que o absurdo libera o homem de sua "vida maquinal" no mundo cotidiano, em qual ele procura fugir da estranheza que assola sua existência. Com efeito, em uma vida maquinal, sem brilho, o tempo nos leva passivamente. Inseridos no lugar comum do cotidiano, somos arrastados pela banalidade de uma vida tida como bem-sucedida, e nos ocultamos "por trás do horário do escritório e do canteiro de obras (esses horários contra os quais protestamos tão alto e que nos 
defendem com tanta segurança do sentimento de estar só)" (CAMUS, 2007, p. 96). Em $A$ queda, Camus, por meio da personagem Clamence, denomina isso de "vida limpa":

\begin{abstract}
Naturalmente, deve ter ouvido falar dos minúsculos peixes dos rios brasileiros [piranhas] que se atiram aos milhares sobre o nadador imprudente, e limpam-no, em alguns instantes, com pequenas mordidas rápidas, deixando apenas um esqueleto imaculado? Pois bem, é esta a organização deles.

- Quer ter uma vida limpa? Como todo mundo? É claro que a resposta é sim. Como dizer não?

- Está bem. Pois vai ficar limpo. Pegue aí um emprego, uma família, férias organizadas. E os pequenos dentes cravam-se até os ossos. Mas estou sendo injusto. Não se deve dizer que a organização é deles. Ela é nossa, afinal de contas: é o caso de saber quem vai limpar o outro. (CAMUS, s/d, p. 8-9)
\end{abstract}

Todavia, chega um momento na vida de um sujeito em que ele, de súbito, flagra-se com trinta anos e sente-se convocado a situar-se no tempo e nele ocupar ativamente seu lugar (CAMUS, 2004). É convocado a perceber sua condição de estrangeiridade; trata-se da queda diante da imagem daquilo que somos, essa náusea, fastio, nojo - em suma, chega um momento em que o homem é solicitado a reconhecer o absurdo. O primeiro sinal do absurdo reconhecido pelo homem se dá quando este responde, de forma sincera, sobre a natureza de seus pensamentos, com o eloquente vazio de sua alma, em que se rompem os grilhões do gesto cotidiano e com o coração que, em vão, procura o elo que lhe falta.

Acredita, pois, viver sob metas e promessas e poder contar com o futuro: "deixa para amanhã", "depois", "mais tarde" etc. O sujeito avalia suas possibilidades, conta com a aposentadoria, com o trabalho dos filhos, com o progresso posterior, em suma: "ainda acredita que alguma coisa em sua vida pode ser dirigida" (CAMUS, 2004, p. 68). No entanto, no momento da consciência, o absurdo entra na vida do homem e, assim, seu espírito pode abandonar a ressecada estrada do vão esforço da esperança, isto é, da busca nostálgica da unidade - o homem, enfim, desaprende a esperar: "o inferno do presente é finalmente seu reino" (CAMUS, 2004, p. 64). Uma vez reconhecido o absurdo, tudo se abala:

a ideia de que "existo", minha maneira de agir como se tudo tivesse um sentido (mesmo que, eventualmente, eu diga que nada tem), tudo isso acaba sendo desmentido de maneira vertiginosa pelo absurdo de uma morte possível. (CAMUS, 2004, p. 68-69)

Sendo assim, reconhecer e aceitar o absurdo significa ter a consciência desse divórcio. O que há em comum entre Sísifo e o trabalhador de rotina 
maquinal é que ambos estão mergulhados na condição absurda; todavia, a diferença fundamental é que em Sísifo há a consciência de tal condição, o que o torna um herói do absurdo (GUIMARÃES, 1971, p. 60). Exemplo literário emblemático dessa condição são as confissões de Jean-Baptiste Clamence, do referido texto A queda. Clamence era, de fato, muito bem-sucedido em sua "vida maquinal":

um homem na força da idade, com a saúde perfeita, generosamente dotado, hábil tanto nos exercícios do corpo quanto da inteligência, nem pobre nem rico, de sono fácil, e profundamente satisfeito consigo mesmo. (CAMUS, s/d, p. 24)

Aliás, ele se considerava mesmo "um pouco super-homem" (CAMUS, s/d, p. 25). A história de Clamence é o caso típico do homem de que, em certo momento da vida, é solicitado encarar o absurdo - podendo encará-lo ou escapar dele. A queda do personagem consiste em sair de sua "vida de sucesso", sempre mantida no alto - "viver no alto é ainda a única maneira de ser visto e saudado pela maioria das pessoas (CAMUS, s/d, p. 23) ${ }^{13}$-, para o reconhecimento de sua estrangeira e miserável criatura:

Quanto mais me acuso, mais tenho o direito de julgar os outros. Melhor, provoco as pessoas no sentido de se julgarem, o que me consola igualmente. Ah, meu caro, nós somos estranhos, miseráveis criaturas e, por pouco que nos debrucemos sobre nossas vidas, não faltam ocasiões para nos espantarmos e nos escandalizarmos a nós mesmos. (CAMUS, s/d, p. 96)

Nesse sentido, se o homem pretende não negar a separação entre ator e palco, deve ser, pois, por meio da consciência do fosso entre homem e mundo. Deve então sustentar esse divórcio através de uma consciência perpétua, sempre renovada, sempre tensa: "Nesse momento [da consciência], o absurdo, ao mesmo tempo tão evidente e tão difícil de conquistar, entra na vida de um homem e reencontra a sua pátria" (CAMUS, 2004, p. 64). Aceitar o absurdo é ter consciência dele; no momento da queda (leia-se no momento em que o homem absurdo é solicitado àquilo), ele pode: suicidar-se fisicamente, suicidar-se filosoficamente (escapar pelo salto religioso), fazer do mundo uma casa de conceitos e de formas à medida humana, ou... manter a aposta dilacerante do absurdo, que significa a mesma coisa que viver sem apelar. Neste mundo de religiões e religiões sem deuses, o único pecado que o homem pode conhecer é o de negar o único mundo ao qual tem acesso, precisamente o mundo que marcha ao acaso, que é estranho a ele e a ele escapa

${ }^{13} \mathrm{O}$ "super-homem" Clamence gostava de ficar "acima das formigas humanas" (CAMUS, s/d, p. 22). 
apresentando-se tal como é. Assim, o homem encontra o vinho do absurdo e o pão da indiferença que nutrirão sua grandeza humana: "Pode então decidir aceitar a vida em semelhante universo e dele extrair suas forças, sua recusa à esperança e o testemunho obstinado de uma vida sem consolo" (CAMUS, 2004, p. 71).

\section{5. (OS LIMITES DA) VIZINHANÇA CONCEITUAL ENTRE HEIDEGGER E CAMUS}

Em vista do exposto, sugere-se Heidegger como relevante inspiração filosófica a Camus, principalmente ao se levar em conta o forte parentesco da economia interna dos dois conceitos que tentamos examinar. Conclui-se: Camus leitor de Heidegger. É preciso, nesse sentido, finalizar a comparação entre os dois autores através de uma identificação sintética dos pontos de maior aproximação, que recaem nos temas: condição humana, estranheza ou estrangeiridade e existência autêntica ou liberação da "vida maquinal". Ao cabo, faz-se imprescindível destacar adequada e pertinentemente, por outro lado, os limites de uma proximidade conceitual entre os dois filósofos contemporâneos abordados em nosso texto.

Nota-se uma vizinhança conceitual entre angústia e absurdo, a começar pela seguinte condição que ambas as concepções designam: um estado essencial a partir do qual se desenrolam as possíveis atitudes do homem. Pelo lado de Heidegger, a angústia está como condição ontológica do Dasein fundamentalmente por duas razões: (i) porque ela permite acessar a totalidade originária mais básica e elementar da estrutura do Dasein (a cura) e, além disso, Heidegger busca a angústia na própria estrutura ontológica do Dasein; (ii) diferentemente do fenômeno do temor, a angústia se angustia com o mundo como tal (e não com determinada região), e isso significa que a própria constituição fundamental do Dasein já propicia a possibilidade da angústia, visto que "mundo" é em si mesmo um constitutivo do Dasein - ou seja, a angústia está ligada ao próprio ser-no-mundo como tal. Por outro lado, para Camus o absurdo também está como condição do homem; por exemplo, ele reitera numerosas vezes que o absurdo não depende da vontade do homem, quer dizer, o absurdo é estado fundamental da condição humana, independentemente de sua vontade. Ele, ademais, explicita que o absurdo é condição do homem, principalmente considerando que tal conceito exprime aquilo que depende da coexistência entre homem e mundo - o absurdo não jaz especificamente no homem nem no mundo, mas na própria separação entre 
os dois. Assim, o que os une é justamente o que os separa: o absurdo. Daí o porquê de Camus rejeitar veementemente a esperança e o suicídio como soluções para o absurdo: o suicídio mata (nega) o homem e a esperança nega (mata) este mundo.

Outra aproximação conceitual entre angústia e absurdo diz respeito a uma determinada forma de existir, a saber, a de se ter perdido a totalidade de sentidos orgânicos com o mundo. Angústia e absurdo remetem à estrangeiridade do homem, remetem à total falta de sentido. Com efeito, a disposição da angústia implica, pelo lado de Heidegger, o fenômeno originário do Dasein de sentir-se estranho, o que ocorre porque aquilo que a angústia traz à tona é o nada, isto é, a ausência de thelos no mundo. Outra razão pela qual a angústia implica o fenômeno originário da estranheza se deve ao fato de que ela revela o próprio Dasein de forma nua e crua e, portanto, revela-o também despido de qualquer sentido. A angústia é a chave de acesso à existência autêntica justamente porque ela despe o Dasein de seu envolvimento significativo, desnudando-o, então, em seu ser-próprio nu e cru, em seu próprio poder-ser. Por conseguinte, visto que a angústia descobre o Dasein nu e cru e seu mundo indiferente, podemos concluir, com Heidegger, que a angústia faz com que achemos tudo "estranho" (sem lar). Quer dizer, a angústia retira o Dasein de seu empenho decadente no "mundo", rompendo então a familiaridade tranquila de seu cotidiano.

Por outro lado, nota-se que o absurdo também implica, pelo lado de Camus, a seguinte condição humana: a de sentir-se estrangeiro. Em primeiro lugar, isso se dá porque aquilo que o absurdo libera é justamente a total falta de sentido que jaz na relação homem-mundo. Nesse sentido, relacionar-se com o mundo nu e cru, isto é, despido de sentido, significa em Camus relacionar-se com o mundo de forma "desumana", rejeitar o recurso inteligível de mensuração (de medidas humanas) e enxergar o mundo apenas sensivelmente, tal como se apresenta. Assim, perceber que no fundo de toda beleza jaz algo de desumano equivale a notar que o mundo escapa ao homem e volta a ser ele mesmo. Conclui-se, conforme exposto, que o absurdo e a angústia possuem um elo, por excelência, com a condição de estrangeiridade humana. O sentido comum a ambos os conceitos devolve ao ente humano sua pureza originária, sua inocência fundamental, e dessa forma indica a retirada daquelas vestes de sentido que o homem originariamente não tem: não havia nenhuma diferença entre Rieux e Tarrou quando nus mergulharam em um indiferente mar (CAMUS, 2001, p. 178).

Mais uma afinidade que poderíamos apontar entre os dois conceitos aqui em questão diz respeito à possibilidade de o homem de sair de sua impessoalidade cotidiana, quer dizer, à possibilidade de o homem de sair do modo impessoal de existir em 
uma vida maquinal. Assim, conclui-se que a concepção heideggeriana de angústia libera o Dasein da decadência do mundo cotidiano, onde ele procura fugir da estranheza que assola sua existência. Atingido pela angústia, o Dasein não é mais pulverizado no modo de ser dos outros, isto é, compreende-se a partir de si próprio e não mais a partir dos outros. O Dasein não é mais dominado pelo que impessoalmente se considera, mas por seu próprio ser, que está em jogo. Por outro lado, pode-se a afirmar, também, que a concepção camusiana de absurdo libera o homem de sua "vida maquinal" no mundo cotidiano, onde ele procura fugir da estranheza que assola sua existência. $\mathrm{O}$ homem acredita viver sob metas e promessas e poder ainda contar com o futuro: "deixa para amanhã", "depois", "mais tarde”; todavia, no momento da consciência, o absurdo entra na vida do homem, e assim seu espírito pode abandonar a busca nostálgica da unidade. Desse modo, reconhecer e aceitar o absurdo significa ter a consciência desse divórcio. O que torna Sísifo um herói do absurdo é estar consciente de sua condição absurda.

Em vista do exposto, sugere-se Martin Heidegger como uma relevante inspiração filosófica a Albert Camus, principalmente levando em conta o forte parentesco da economia interna dos dois conceitos que tentamos examinar - angústia e absurdo. Todavia, observa-se que a diretriz proposta neste texto depara-se com algumas ressalvas que, caso passassem despercebidas, constituiriam um equívoco de nosso trabalho. Dentre elas se sublinha: Heidegger é pensador do sentido do ser - "O pensamento de Heidegger é uma tentativa de dar conta da pergunta pelo ser" (LOPARIC, 2004, p. 59); Camus, por sua vez, trata fundamentalmente do próprio homem. Heidegger (pelo menos o Heidegger de Ser e tempo) debruça-se sobre a estrutura originária do Dasein - portanto, sobre caracteres fundantes -, ao passo que Camus, nesse raciocínio, volta-se para o que há de derivado - portanto, caracteres fundados. Grosso modo, isso significa: os conceitos por nós examinados - em uma tentativa de aproximação - estão inseridos em projetos filosóficos cujas finalidades são consideravelmente distintas. A filosofia camusiana orienta-se para uma afirmação cada vez mais veemente do homem, e não seria decisiva se assim não fosse; já Heidegger tem como meta mais imediata explicitar fenomenalmente a estrutura originária do ser do Dasein, tarefa à altura apenas de uma analítica existencial, segundo diz. ${ }^{14}$ Faz-se necessário, então, destacar que os conceitos de angústia e de absurdo estão inseridos em projetos filosóficos consideravelmente diferentes.

14 "Em sua fase preparatória, a analítica existencial do Dasein tem como tema orientador a constituição fundamental desse ente, o ser-no-mundo. A sua meta mais imediata consiste em explicitar fenomenalmente a estrutura uniforme e originária do ser do Dasein que determina ontologicamente suas possibilidades e modos 'de ser'." (HEIDEGGER, 1988, p. 184) 
Um dos elementos-chave da explicitação camusiana do sentido de absurdo é a consciência. Sísifo é o "herói do absurdo", segundo Camus, justamente porque reconhece e aceita o absurdo, o que significa ter a consciência do divórcio entre homem e mundo, ator e palco:

Sísifo é o grande mestre que nega os deuses erguendo o rochedo. E o homem comum, jogado numa série de tarefas repetidas e exaustivas, se é consciente, alcança aquela superioridade sobre seu destino. E terá que ser feliz. (GUIMARÃES, 1971, p. 60, grifo nosso)

Quer dizer, o que há em comum entre Sísifo e o trabalhador de rotina maquinal, por assim dizer, é a condição de acordo com a qual ambos estão mergulhados no absurdo. A diferença, porém - e isso o torna um "herói do absurdo" -, é que Sísifo tem a consciência dessa condição. Aceitar o absurdo é ter consciência dele. No momento da consciência, segundo Camus, o absurdo entra na vida do homem e, assim, seu espírito pode abandonar o vão esforço da esperança (isto é, da busca nostálgica da unidade). Na consciência do absurdo, o homem, enfim, desaprende a esperar: "o inferno do presente é finalmente seu reino" (CAMUS, 2004, p. 64).

Se o homem pretende não negar a separação entre ator e palco - conforme a proposta positiva de Camus com o conceito de absurdo -, isso deve ser feito justamente por meio da consciência do fosso entre homem e mundo. Ele deve, então, sustentar esse divórcio através de uma consciência perpétua, sempre renovada, sempre tensa. "Nesse momento [da consciência], o absurdo, ao mesmo tempo tão evidente e tão difícil de conquistar, entra na vida de um homem e reencontra a sua pátria" (CAMUS, 2004, p. 64). Ter consciência, nesse caso, equivale a manter a aposta dilacerante do absurdo, o que significa a mesma coisa que aceitar o mundo que marcha ao acaso, que é estranho a ele e a ele escapa apresentando-se tal como é. Eis o absurdo então: "Saber-se finito e viver. Ter plena consciência do sem-sentido e viver" (GUIMARÃES, 1971, p. 60). O homem encontra o vinho do absurdo e o pão da indiferença que nutrirão sua grandeza humana: "Pode então decidir aceitar a vida em semelhante universo e dele extrair suas forças, sua recusa à esperança e o testemunho obstinado de uma vida sem consolo" (CAMUS, 2004, p. 71). O meio pelo qual permanecemos no absurdo, nesse sentido, é manter a consciência dele. Por outras palavras, a consciência do absurdo significa de alguma forma a manutenção do confronto desesperado entre a interrogação humana e o silêncio irracional do mundo. 
Martin Heidegger, por sua vez, tem como principal objetivo - em Ser e tempo - a elaboração e explicitação da questão do sentido do ser. Indício disso é a citação que o autor coloca na primeira página da obra mencionada, a saber, uma citação de $O$ sofista, de Platão: "pois é evidente que de há muito sabeis o que propriamente quereis designar quando empregais a expressão 'ente'. Outrora, também nós julgávamos saber, agora, porém, caímos em aporia" (HEIDEGGER, 1988, p. 24). Essa passagem constata, por um lado, que a questão do ser jaz sem solução na filosofia platônica, e - por que não? -, de modo geral no pensamento grego, e ao mesmo tempo indica de alguma forma que a aporia em relação ao significado do termo "ente" também persiste, de maneira aguda, até nossos dias. Todavia, visto que o problema do ser permanece em aporia desde os primórdios da filosofia ocidental, em que consiste então a particularidade da abordagem heideggeriana dessa questão?

O livre professor Heidegger de 1927 observa a necessidade de se colocar em questão como é o ser e não o que é o ser. O corolário disso é que o autor procura no ser do ente humano não mais uma essência fixa ou substância distintiva - conforme o humanismo do qual, de alguma forma, a filosofia camusiana se aproxima -, mas sim seus possíveis modos de ser em termos de possibilidades existenciais do estar-aí humano:

Diferentemente da tradição, para a qual a essência estava radicalmente desarticulada da existência e possuía um modo de ser a priori, a concepção heideggeriana do ser-aí humano o articula essencialmente com seu existir. Antes de sua dinâmica existencial, o ser-aí não é essencialmente nada e tudo que ele é precisa ser por ele conquistado como um modo de ser. (CASANOVA, 2009, p. 128)

De início podemos afirmar que a questão acerca do sentido do ser se mostra possível a partir do ente, que é simultaneamente tema e a questão em vista da qual a pergunta pôde ser colocada, a saber, o Dasein. Ledo engano, no entanto, considerar que o Dasein designa o conceito heideggeriano de homem. ${ }^{15} \mathrm{Na}$ verdade, o termo em questão inviabiliza, por excelência, a própria colocação da pergunta “o que é o homem?”. É na medida em que o Dasein designa um modo de ser radicalmente distinto de todos os entes caracterizados por propriedades quididativas e determinações essenciais que tal pergunta se mostra inviabilizada. O filósofo alemão problematiza e recusa a ideia de subjetividade, de razão inata, de intuição e de introspecção. Em si e por si mesmo, Dasein não possui uma "razão", um "corpo", uma

\footnotetext{
${ }^{15}$ Segundo Heidegger, daí o porquê não ser "por capricho terminológico que evitamos o uso desses termos bem como das expressões 'vida' e 'homem' para designar o ente que nós mesmos somos" (HEIDEGGER, 1988, p. 82). Para Benedito Nunes (1992, p. 75), Heidegger utiliza a palavra "Dasein" pois ela expressa puramente o ser neutralizando qualquer ideia prévia de natureza humana.
} 
"alma" ou qualquer outra faculdade na condição de apanágio: do ponto de vista de uma condição mais originária, o Dasein sequer tem "vida" - todos esses elementos são fundados, e não fundantes, isto é, originários.

Assim, conceitos como "homem" e "consciência" - tão caros a Camus, já que aceitar o absurdo é ter consciência dele - contrapõem-se ao projeto heideggeriano de Ser e tempo, tendo em vista que não estão implicados no fenômeno originário do Dasein. Os 83 parágrafos do tratado incompleto publicado em 1927 lançam bases para a superação das (tradicionais) teorias da consciência e da representação, por estas sempre se fundamentarem, em última instância, na relação sujeito-objeto. $\mathrm{Na}$ perspectiva heideggeriana, o significado de consciência tal como arrolado pelo pensamento camusiano ainda diz respeito, por assim dizer, a uma relação puramente privada do homem consigo mesmo, na qual ele se desliga do objeto externo e por isso retorna a si. A consciência, nessa acepção filosófica, diz respeito a uma relação "interior" ou "espiritual" supostamente intrínseca ao homem, pela qual ele pode se conhecer de modo privilegiado e assim julgar-se de forma segura. Essa definição de consciência, portanto, corresponde à esfera da interioridade: “o reconhecimento de uma realidade interior privilegiada só existe nas filosofias que assumem como tema a oposição entre 'interioridade' e 'exterioridade"” (ABBAGNANO, 1998, p. 186). Aqui, uma consciência lança seu olhar para o mundo, objeto externo, e projeta uma representação sobre essa exterioridade. Trata-se, então, de um paradigma segundo o qual há explícita separação ontológica entre intelecto e coisa, sujeito e objeto, consciência e mundo.

Nesse sentido, pergunta-se: o que diferencia Heidegger da posição camusiana no tocante a tal paradigma? A fim de criticar o então inatacável primado da relação subjetividade-objetividade, que para Heidegger é tão verdadeira quanto vã, o autor de Ser $e$ tempo traz à tona a constituição fundamental do Dasein de ser-no-mundo:

[...] o ser-no-mundo constitui uma armação rígida dentro da qual se desenrolam as possíveis atitudes e comportamentos do Dasein com seu mundo, sem que se altere ou mesmo se toque na estrutura ontológica da própria "armação". (HEIDEGGER, 1988, p. 238)

Como ser-no-mundo, o Dasein não sai de uma consciência interna "encapsulada" e isolada; antes, desde sempre esteve "fora", isto é, sempre esteve "no" mundo, que por isso mesmo sempre foi de alguma forma descoberto pelo Dasein. Na medida em que o Dasein confere abertura a seu ser, ele já está-no-mundo; com isso observa-se o corolário segundo o qual, do ponto de vista ontológico, só há "mundo" porque 
Dasein existe/abre-se, e Dasein existe/abre-se porque há "mundo". A expressão "ser-nomundo" designa um existencial por excelência unitário e indivisível, de sorte que não há Dasein sem mundo (pois só “é” no mundo), e não há mundo sem Dasein.

Ser e tempo inaugura uma forma nova de conceber e situar o fenômeno da consciência, concebendo-a não mais como fundamento das teorias da subjetividade; o tratado procura situar a consciência enquanto radicada no ser-no-mundo (essa é a diferença de paradigma para com Camus). Em primeiro lugar, o filósofo alemão busca conceber a consciência como um fenômeno por excelência existencial, e Heidegger propõe-se, portanto, abordar o fenômeno da consciência em sua investigação puramente existencial, com vistas a sua ontologia fundamental. Essa análise ontológica antecede as considerações camusianas no tocante à consciencia; ademais, a consideração ontológica conferida por Heidegger evita vias interpretativas que reconduzam a definição de "consciência a uma das faculdades da alma, entendimento, vontade ou sentimento, ou a explica como uma mistura desses elementos" (HEIDEGGER, 2005, p. 57).

Nesse raciocínio é possível notar distinções importantes entre os projetos de Heidegger (pensador do sentido do ser) e de Camus (que trata propriamente do "homem"): o problema que Ser e tempo tematiza é anterior (em termos de mais originário) do que qualquer "tomada de consciência" tal como se dá com Sísifo, "herói do absurdo". A (tomada de) consciência tal como arrolada na problemática camusiana está no mesmo nível das problemáticas próprias à antropologia, à psicologia, à biologia ${ }^{16}$ ou das teorias baseadas na subjetividade, e isso, grosso modo, por uma razão: são problemáticas que se debruçam sobre um fenômeno derivado, fundado, e por isso mesmo não fundamental, da constituição do ente humano - diferente da disposição da angústia, esta sim fundamental, já que, segundo Heidegger, o que originariamente é próprio do Dasein diz respeito à disposição, à compreensão e ao discurso, no sentido de que são essas as estruturas existenciais que compõem a abertura primordial do ser-no-mundo: "Enquanto existenciais, a disposição e compreensão caracterizam a abertura originária do ser-no-mundo" (HEIDEGGER, 1988, p. 204). Corrobora-se tal raciocínio quando se observa que as vias interpretativas as quais Heidegger descarta em sua análise existencial da consciência em Ser e tempo não são tomadas

\footnotetext{
${ }^{16}$ Em Ser e tempo, Heidegger considera que tais ciências não visam em absoluto ao Dasein, e sim a regiões específicas do fenômeno em questão, tais como alma, espírito e corpo. Quando se coloca, porém, a questão propriamente ontológica do ser do ente que nós somos, torna-se inviável coisificá-lo como soma de alma, espírito e corpo: reduzir o ser do único ente ek-sistente a um desses elementos ou mesmo à soma deles é o mesmo que descartar a ideia de ser da totalidade. "O simplesmente dar-se em conjunto do físico e do psíquico é, do ponto de vista ôntico e ontológico, inteiramente distinto do fenômeno do ser-no-mundo." (HEIDEGGER, 1988 , p. 271, grifo do autor)
} 
em momento algum como incorretas ou falsas, a serem refutadas; na verdade, o autor as vê como derivações do enraizamento ontológico abordado por ele. Heidegger não se posiciona veementemente contra cada uma dessas interpretações - antropológica, psicológica, biológica etc. - a fim de tomá-las como incorretas, mas procura explorar justamente o fundamento ontológico-existencial da consciência a partir do qual se dão as derivações sobre as quais cada uma dessas interpretações se debruça. Numa palavra: todas essas interpretações se referem a derivações do fenômeno existencial da consciência, e nesse sentido Heidegger visa precisamente àquilo que possibilita derivar tais interpretações - ele busca pelo fundante e não pelo fundado.

Assim, para Heidegger a consciência "é" e se anuncia tão somente com e na existência do Dasein: "no contexto problemático desse tratado, a análise da consciência encontra-se unicamente a serviço da questão ontológica fundamental" (HEIDEGGER, 2005, p. 78). A consciência enquanto caractere ontológico por excelência radicado no Dasein é abordada, pelo Heidegger de Ser e tempo, como uma modalidade existencial (Existenzial), assim como todos os caracteres ontológicos enraizados no Dasein, visto que "eles se determinam a partir da existencialidade" (HEIDEGGER, 1988, p. 80).

Com efeito, procurou-se evidenciar, em adendo, as diferenças dos projetos filosóficos de Camus e Heidegger tendo em vista a distinção de paradigma. A importância da questão da consciência na explicitação camusiana do sentido do absurdo diferencia-se de modo notável da perspectiva heideggeriana. Por um lado, é certo que Heidegger é relevante influência teórica a Camus; por outro, é preciso destacar que tal proximidade tem seus limites e atritos na medida em que os dois filósofos apresentam projetos com finalidades distintas. Assim, o escopo deste texto limita a certeza de suas conclusões e por isso mesmo propõe uma ligação interna entre ambos os autores da contemporaneidade levando em conta os limites de tal ligação. Sugerem-se com isso outras pesquisas quanto à trajetória intelectual de Camus marcada especificamente pelo alcance heideggeriano - no sentido de oportunizar uma via (ainda não muito habitual) que enriqueça ainda mais o campo filosófico próprio a ele.

\section{CONSIDERAÇÕES FINAIS}

cada artista conserva dentro de si uma fonte única, que alimenta durante a vida o que ele é e o que diz.

(CAMUS, 2007, p. 17) 
Procurou-se sugerir e examinar certa proximidade, do ponto de vista filosófico, entre Martin Heidegger e Albert Camus, em particular entre a concepção heideggeriana de angústia (Ser e tempo) e o pensamento absurdo camusiano ( $O$ mito de Sísifo), ainda que - conforme se procurou explicitar na parte 4 - seja ela uma proximidade que ocorre com certos atritos e contrastes. Verifica-se a relevância de uma vizinhança conceitual entre as duas concepções aqui em questão através da possibilidade de se ir além das principais vertentes que muitas vezes classificam Camus como mero ilustrador literário de teses filosóficas. Dessa forma, dialoga-se com os críticos de Camus (como Sartre) quanto a uma suposta imprecisão conceitual da definição de absurdo: procurou-se indicar que o absurdo encerra uma condição fundamental em que o homem está inevitavelmente lançado ao mundo - tal qual a estrutura heideggeriana de ser-no-mundo -, condição essa que é a própria possibilidade de surgimento da angústia. Assim, tal proximidade nos oportuniza um acesso (ainda não muito visitado) ao âmbito filosófico próprio a Camus. 


\section{REFERÊNCIAS BIBLIOGRÁFICAS}

ABBAGNANO, Nicola. Dicionário de filosofia. 3 ed. Trad. Alfredo Bosi. São Paulo: Martins Fontes, 1998.

BRISVILLE, Jean-Claude. Albert Camus. Lisboa: Editorial Presença, 1962.

CAMUS, Albert. A peste. 7 ed. Trad. Valerie Rumjanek. Rio de Janeiro: Record, 2001.

. A queda. Trad. Valerie Rumjanek. Rio de Janeiro: Record, s/d.

. O avesso e o direito. 6 ed. Trad. Valerie Rumjanek. Rio de Janeiro: Record, 2007. . O estrangeiro. 14 ed. Trad. Valerie Rumjanek. Rio de Janeiro: Record, 1995. . O homem revoltado. 7 ed. Trad. Valerie Rumjanek. Rio de Janeiro: Record, 2008.

O mito de Sísifo. Trad. Ari Roitman e Paulina Watch. Rio de Janeiro: Record, 2004

CASANOVA, Marco Antônio. Compreender Heidegger. Petrópolis, RJ: Vozes, 2009. DOSTOIEVSKI, Fiódor. Os irmãos Karamázov. Rio de Janeiro: Abril Cultural, 1971.

DUROZOI, Gerard; ROUSSEL, Andre. Dicionário de filosofia. 2 ed. Trad. Marina Appenzeller. Campinas: Papirus, 1999.

FERREIRA, Aurélio Buarque de Holanda. Novo Dicionário da Língua Portuguesa. 2 ed. rev. e aumentada. Rio de Janeiro: Nova Fronteira, 1986.

FONSECA, Ludmilla C. O homem extraordinário de Fiódor Dostoiévski e o homem revoltado de Albert Camus. 124 f. Dissertação de Mestrado - Universidade Brasília, Brasília, 2010.

GERMANO, Emanuel R. O pensamento dos limites: contingência e engajamento em Albert Camus. 498 f. Tese de Doutorado - Universidade de São Paulo, São Paulo, 2007.

GUIMARÃES, Carlos Eduardo. As dimensões do Homem - Mundo, Absurdo, Revolta (Ensaio sobre a filosofia de Albert Camus). Rio de Janeiro; Paz e Terra: 1971.

HEIDEGGER, Martin. Ser e tempo - parte I. 2 ed. Trad. Márcia de Sá Cavalcante. Petrópolis: Vozes, 1988.

Ser e tempo - parte II. 12 ed. Trad. Marcia Sá Cavalcante Schuback.

Petrópolis: Vozes, 2005. 
INWOOD, Michael. Dicionário Heidegger. Trad. Luísa Buarque de Holanda. Rio de Janeiro: Jorge Zahar, 2002.

LOPARIC, Zeljko. Heidegger. Rio de Janeiro: Jorge Zahar, 2004.

MACHADO, Patrícia O. Absurdo, revolta, ação: Albert Camus. 106 f. Dissertação de Mestrado - Universidade de Brasília, Brasília, 2010.

MOUNIER, Emmanuel. A esperança dos desesperados - Malraux, Camus, Sartre, Bernanos. Rio de Janeiro: Paz e Terra, 1972.

NUNES, Benedito. Passagem para o poético - filosofia e poesia em Heidegger. 2 ed. São Paulo: Ática, 1992.

PASCAL, Blaise. Coletânea do pensamento de Pascal. Org. Maurice François. São Paulo: Martins Fontes, 1965; . Pensamentos. 3. ed. São Paulo: Abril Cultural, 1984.

PEREIRA, Newton G. O ser da política e a política do ser: o confronto entre Hannah Arendt e Martin Heidegger em Ser e Tempo. 141 f. Tese (Doutorado) - Universidade Estadual de São Paulo (USP), São Paulo, 2008.

PIMENTA, Danilo R. A criação absurda segundo Albert Camus. 120 f. Dissertação de Mestrado - Universidade Federal de Ouro Preto, Ouro Preto, 2010.

RESWEBER, Jean-Paul. O pensamento de Martin Heidegger. Trad. João Agostinho A. Santos. Coimbra: Livraria Almedina, 1979.

SAFRANSKI, Rüdiger. Heidegger - um mestre da Alemanha entre o bem e o mal. Trad. Lya Luft. São Paulo: Geração Editorial, 2000.

SARTRE, Jean-Paul. Situações I - críticas literárias. Trad. Cristina Prado. São Paulo: Cosac Naify, 2005.

SIMON, Pierre-Henri. O homem em processo: Malraux, Sartre, Camus e SaintExupéry. Lisboa: Portugália Editora, s/d.

STEGMÜLLER, Wolfgang. A filosofia contemporânea: introdução crítica. São Paulo: EPU, 1977.

STEIN, Ernildo. Seis estudos sobre Ser e tempo. 3. ed. Petrópolis: Vozes, 2005. 


\section{AGRADECIMENTOS}

Agradeço à companheira de estudos, graças a quem entrei em contato pela primeira vez com a obra de Albert Camus, autor decisivo em minha inicial formação: muito obrigado, Rafaela Magalhães de Paula, pela parceria acadêmica. Agradeço ao parecerista anônimo pelos comentários e sugestões, que foram determinantes para a finalização deste artigo. 